\title{
FERMENTE SUCUKTAN İZOLE EDILEN MUNDTİSİN KS ÜRETİCİSİ ENTEROCOCCUS MUNDTII YB6.30 SUŞUNUN TEKNOLOJİK ÖZELLİKLERİ VE GÜVENLİK DEĞERLENDİRMESİ*
}

\author{
Melike Kasap, Yasin Tuncer** \\ Süleyman Demirel Üniversitesi, Mühendislik Fakültesi, Gıda Mühendisliği Bölümü Isparta, Türkiye \\ Geliş / Received: 10.06.2019; Kabul / Accepted: 17.08.2019; Online bask1 / Published online: 11.09.2019
}

Kasap, M., Tuncer, Y. (2019). Fermente sucuktan izole edilen mundtisin KS üreticisi Enterococcus mundtii YB6.30 suşunun teknolojik özellikleri ve güvenlik değerlendirmesi. GIDA (2019) 44 (5): 866-880 doi: $10.15237 /$ gida.GD19090

Kasap, M., Tuncer, Y. (2019). Technological properties and safety evaluation of mundticin KS producer Enterococcus mundtii YB6.30 strain isolated from fermented sucuk. GIDA (2019) 44 (5): 866-880 doi: 10.15237/gida.GD19090

\section{ÖZ}

Bu çalısmada, mundtisin KS üreticisi Enterococcus mundtii YB6.30 suşunun teknolojik özellikleri ve güvenlik değerlendirmesinin fenotipik ve genotipik yöntemler ile araştırılması amaçlanmıştır. E. mundtii YB6.30 suşunun de Man, Rogosa and Sharpe broth ortamında, yapılandırılmış yağsız süt ortamına göre daha hızlı asit üretim özelliği gösterdiği belirlenmiştir. E. mundtii YB6.30 suşunun proteolitik aktivite gösterdiği ve nitratı redükte ettiği fakat lipolitik aktivite göstermediği tespit edilmiştir. YB6.30 suşu denemelerde kullanılan antibiyotiklerin tamamına duyarlı bulunmuştur. Fenotipik testler sonucu YB6.30 suşunun hemolitik aktivite ve jelatinaz aktivitesi göstermediği belirlenmiştir. Polimeraz zincir reaksiyonu (PZR) ile YB6.30 suşunun virülens faktör içermediği tespit edilmiştir. YB6.30 suşu histidin, lisin ve ornitini dekarboksile edemez iken, tirozinden tiramin ürettiği belirlenmiştir. PZR denemeleri sonucu YB6.30 suşunda yalnız tirozin dekarboksilaz (tdc) geni varllğı tespit edilmiştir. Bu çalısmanın sonuçları mundtisin KS üreticisi E. mundtii YB6.30 suşunun gıda endüstrisinde starter kültür olarak kullanımının güvenli olduğunu göstermiştir.

Anahtar kelimeler: Enterococcus mundtii, sucuk, mundtisin KS, teknolojik özellikler, güvenlik değerlendirmesi

\section{TECHNOLOGICAL PROPERTIES AND SAFETY EVALUATION OF MUNDTICIN KS PRODUCER ENTEROCOCCUS MUNDTIIYB6.30 STRAIN ISOLATED FROM FERMENTED SUCUK}

\begin{abstract}
In this study, investigation of technological properties and safety evaluation of mundticin KS producer Enterococcus mundtii YB6.30 by phenotypic and genotypic methods were aimed. E. mundtii YB6.30 strain has been determined to show a faster acid production properties in de Man, Rogosa and Sharpe broth than reconstituted skim milk. E. mundtii YB6.30 strain showed proteolytic activity and reduced nitrate but not showed lipolytic activity. The YB6.30 strain was found to be sensitive to all antibiotics used in this study. As a result of phenotypic tests, YB6.30 strain did not show hemolytic and gelatinase activities. The YB6.30 strain was not found to contain virulence factor genes using polymerase chain reaction (PCR). The YB6.30 strain was found to produce tyramine from tyrosine while it did not decarboxylate histidine, lysine and ornithine. As a result of PCR experiment, only tyrosine decarboxylase gene $(t d c)$ was detected in YB6.30 strain. The results of this study showed that mundticin KS producer E. mundtii YB6.30 strain was safe to use as a starter culture in the food industry.
\end{abstract}

Keywords: Enterococcus mundtii, sucuk, mundticin KS, technological properties, safety evaluation

* Bu çalışma Melike Kasap’ın yüksek lisans tez çalışmasıdır. Bu çalışmanın bir kısmı International Marmara Science and Social Sciences Congress (IMASCON 2018) Kocaeli/Türkiye'de sözlü sunum olarak sunulmuş ve kongre kitabında bildiri olarak basılmıştır. This paper is MSc thesis of Melike Kasap. This study was presented as a oral presentation at the International Marmara Science and Social Sciences Congress (IMASCON 2018) Kocaeli/Turkey, and a part of this study was published in the book of proceedings.

** Yazışmalardan sorumlu yazar/ Corresponding Author

$\triangle$ yasintuncer@sdu.edu.tr,

(c) (+90) 2462111713

且 (+90) 2462370437 


\section{GİRİ̧̧}

Enterokoklar toprak, yüzey sular1, okyanus suyu, kanalizasyon, bitkiler ve insan ve hayvan gastrointestinal kanalının yanı sira geleneksel yöntemler ile üretilen peynir, sosis vb. fermente gidalardan siklikla izole edilebilen homofermentatif laktik asit bakterileridir (Franz vd., 1999; Giraffa, 2003; Ogier ve Serror, 2008). Laktik asit üretimi, proteolitik aktivite, lipolitik aktivite, sitrat yıkımı ve nitrat redüktaz aktivitesi enterokokların fermente gidaların üretiminde starter kültür olarak kullanımlarını esas teşkil eden teknolojik özellikleridir (Sarantinopoulos vd., 2001; Giraffa, 2003; Foulquié Moreno vd., 2006). Ayrica enterokoklar enterosin olarak isimlendirilen özellikle Listeria türlerine karş1 antimikrobiyal aktivite gösteren bakteriyosinler de üretebilmektedir. Günümüze kadar E. mundtii suşları tarafindan üretilen sinırlı sayıda bakteriyosin tanımlanmıştır. Mundtisin (Bennik vd., 1998), mundtisin KS (Kawamoto vd., 2002), mundtisin CRL35 (Saavedra vd., 2004), mundtisin QU2 (Zendo vd., 2005) ve mundtisin L (Feng vd., 2009) E. mundtii suşları tarafindan üretildiği bildirilmiş bakteriyosinlerdir. Mundtisin KS, 43 amino asitten oluşan ve E. mundtii, E. faecium, E. faecalis ve L. monocytogenes'e karşı etkili olan bir peptiddir (Kawamoto vd., 2002).

Enterokoklar sahip olduğu teknolojik özelliklerin yanı sıra endokardit, merkezi sinir sistemi, üriner sistem enfeksiyonları, bakteriyemi, karın içi ve pelvik enfeksiyonlarına sebep olan hastane kaynaklı (nozokomiyal) patojenler olarak da tanımlanmaktadırlar (Foulquié Moreno vd., 2006; Reyes vd., 2017). Bu nedenle starter veya probiyotik kültür olarak kullanılacak enterokok suşlarının endüstriyel özelliklerinin yanı sıra güvenlik değerlendirmelerinin de yapılması gerekmektedir (Inoğlu ve Tuncer, 2013). Enterokoklarnn patojenitesi, virülens faktör içermeleri ve çoklu antibiyotik direncine sahip olmalarından ileri gelmektedir. Enterokoklarda tanımlanmış başlıca virülens faktörler agregasyon maddesi, kollojen bağlayan protein, endokarditis spesifik antijeni, enterokokal yüzey proteini, sitolizin, jelatinaz, hiyalüronidaz ve seks feromonlarıdır (Chajęcka-Wierzchowska vd., 2017). Enterokoklar antibiyotiklere karşı hem doğal (intrinsik) hem de kazanılmış (aktarılabilir) direnç gösterebilmektedir (Klare vd., 2001). Enterokoklar sefalosporinler, aminoglikozidler, klindamisin ve trimetoprim-sülfametoksozole doğal direnç gösterirken, mutasyon veya direnç genlerinin yatay transferi yolu ile yüksek seviyede aminoglikozid, yüksek seviyede ampisilin, vankomisin veya diğer antibiyotiklere direnç kazanabilmektedirler (García-Solache ve Rice, 2019). Çoklu antibiyotik dirence sahip enterokok suşları (iki veya daha fazla antibiyotik sınıfına dirençli) dünya genelinde hastalıkların tedavisinde sayisiz sorunlara neden olmaktadır (Shokoohizadeh vd., 2018). Enterokokların tüketici sağlığı açısından risk teşkil eden diğer bir özellikleri biyojen amin üretmeleridir. Biyojen aminler, amino asitlerin mikrobiyal dekarboksilasyonu yolu ile oluşan toksik bileşiklerdir. Fermente gidalardan izole edilen enterokokların genel olarak tirozini dekarboksile ederek tiramin ürettiği bilinmektedir (Inoğlu ve Tuncer, 2013; Barbieri vd., 2019).

$\mathrm{Bu}$ çalışmada fermente sucuktan izole edilmiş mundtisin KS üreticisi Enterococcus mundtii YB6.30 suşunun hem teknolojik özellikleri (laktik asit üretimi, proteolitik aktivite, lipolitik aktivite ve nitrat redüktaz aktivitesi) incelenmiş hem de güvenlik değerlendirmesi (antibiyotik direnç, hemolitik aktivite, jelatinaz aktivitesi, virülens faktör genlerinin tespiti, biyojen amin üretimi ve amino asit dekarboksilaz genlerinin tespiti) yapılarak izolatın starter kültür olarak kullanım potansiyeli araştırlmıştır.

\section{MATERYAL VE YÖNTEM}

\section{Mikroorganizma}

Çalışmada kullanılan mundtisin KS üreticisi Enterococcus mundtii YB6.30 suşu Süleyman Demirel Üniversitesi Gıda Mühendisliği Bölümü, Bakteriyel Genetik Laboratuvar1 kültür koleksiyonundan temin edilmiştir. Bakteriyosin üreticisi E. mundtii YB6.30 suşu de Man, Rogosa and Sharpe broth (MRS, LAB M, Lancashire, UK) ortamında \% $20(\mathrm{v} / \mathrm{v})$ steril gliserol ilave edilerek $-20^{\circ} \mathrm{C}$ 'de muhafaza edilmiştir. Çalışma kültürü ise gliserol ilave edilmemiş MRS broth ortamında +4 ${ }^{\circ} \mathrm{C}$ 'de ve haftalık pasajlama yapılarak muhafaza edilmiştir. 


\section{Laktik asit üretimi}

E. mundtii YB6.30 suşunun asit üretim yeteneği, yapılandırılmıs yağsız süt (RSM, LAB M) (\% 11, $\mathrm{w} / \mathrm{v})$ ve MRS broth ortamlarında test edilmiştir. RSM ve MRS broth ortamlarina aktif YB6.30 kültüründen $\% 1(\mathrm{v} / \mathrm{v})$ oranında ekim yapılmış ve örnekler $30{ }^{\circ} \mathrm{C}$ ve $37{ }^{\circ} \mathrm{C}$ 'de inkübasyona bırakılmıştır. İnkübasyonun $0 ., 6$. ve 24 . saatleri sonunda besiyeri ortamlarından örnek alınarak kültür pH's1 pH metre (WTW 3110, Almanya) yardımıyla ölçülmüştür. Kültürün asit üretim yeteneği başlangiç $\mathrm{pH}$ değeri ile inkübasyon sonrası oluşan $\mathrm{pH}$ değerleri arasındaki fark $(\Delta \mathrm{pH})$ dikkate alınarak hesaplanmıştır (Özkalp vd., 2007).

\section{Proteolitik aktivite}

E. mundtii YB6.30 suşunun proteolitik aktivitesi calcium caseinate agar (Fluka 21065, İsviçre) ortaminda belirlenmiştir. MRS broth ortaminda geliştirilen kültürden mikropipet yardımıyla $10 \mu \mathrm{L}$ calcium caseinate agar ortamına pipetlenmiş ve petri kutuları $37^{\circ} \mathrm{C}$ 'de 3 gün inkübasyona tabi tutulmuştur. Süre sonunda koloni etrafinda zon oluşumu incelenmiş ve zon çapı ölçülmüştür (Martín vd., 2006).

\section{Lipolitik aktivite}

Lipolitik aktivitenin belirlenmesinde spirit blue agar (BD Difco) (Landeta vd., 2013), \% 1 tween 80 veya tween 20 ilave edilmiş MRS agar (Essid vd., 2007) ve tributyrin agar olmak üzere 4 farklı besiyeri ortamı kullanılmıştır. Her bir besiyerine aktif YB6.30 kültüründen mikropipet yardımıla $10 \mu \mathrm{L}$ kültür inoküle edilmiş ve petri kutuları 37 ${ }^{\circ} \mathrm{C}$ 'de 48 saat inkübasyona bırakılmıştır. İnkübasyon süresi sonunda koloni etrafinda opak zon oluşumu incelenmiştir.

\section{Nitrat redüktaz aktivitesi}

Nitrat redüktaz aktivitesi $\% 0.1(\mathrm{w} / \mathrm{v})$ oranında $\mathrm{KNO}_{3}$ içeren $\mathrm{Y} T$ agar ortamında belirlenmiştir (Miralles vd., 1996). YT agar besiyeri ortamina aktif YB6.30 kültüründen mikropipet yardımıyla $10 \mu \mathrm{L}$ kültür pipetlenmiş ve koloni oluşumu için $37{ }^{\circ} \mathrm{C}$ 'de 24 saat inkübasyona bırakılmıştır. İnkübasyon süresi sonunda nitrat reaktifi A (Fluka 38497) ve nitrat reaktifi B (Fluka 39441) eşit hacimde karıştırllarak kolonilerin üstü kapanacak şekilde petri kutularına aktarılmıştır. Reaktif ilavesini takiben koloni renginin kırmızıya dönmesi pozitif sonuç olarak değerlendirilmiştir. Denemelerde nitrat redüktaz pozitif Escherichia coli ATCC 25922 ve Salmonella Typhimurium ATCC 14028 suşları pozitif kontrol olarak kullanılmıştır.

\section{Antibiyotik direnç}

E. mundtii YB6.30 suşunun antibiyotik direnç profili Oxoid Ltd. Şti. (İngiltere)'den temin edilen ampisilin $(10 \mu \mathrm{g})$, penisilin $\mathrm{G}(10 \mathrm{U})$, vankomisin $(30 \mu \mathrm{g})$, teikoplanin $(30 \mu \mathrm{g})$, eritromisin $(15 \mu \mathrm{g})$, tetrasiklin $(30 \mu \mathrm{g})$, doksisiklin $(30 \mu \mathrm{g})$, minosiklin $(30 \mu \mathrm{g})$, siprofloksasin $(5 \mu \mathrm{g})$, levofloksasin $(5 \mu \mathrm{g})$, norfloksasin $(10 \mu \mathrm{g})$, nitrofurantoin $(300 \mu \mathrm{g})$, rifampin (5 $\mu \mathrm{g})$, kloramfenikol (30 $\mu \mathrm{g})$, quinopristin-dalfopristin $(15 \mu \mathrm{g})$, linezolid $(30 \mu \mathrm{g})$, gentamisin $(120 \mu \mathrm{g})$ ve streptomisin $(300 \mu \mathrm{g})$ ticari antibiyotik diskleri kullanılarak disk difüzyon yöntemi ile belirlenmiştir (Yogurtcu ve Tuncer, 2013). Disk difüzyon testlerinde E. faecalis ATCC 29212 suşu kontrol olarak kullanılmıştır. Sonuçlar Klinik ve Laboratuvar Standartlar1 Enstitüsü (Clinical and Standards Institute, CLSI) 2016 kilavuzuna göre değerlendirilmiştir.

\section{Hemolitik aktivite}

Hemolitik aktivite \% 5 (v/v) koyun kanı içeren Columbia agar (Liofilchem, Roseto degli Abruzzi, İtalya) besiyeri ortamında test edilmiştir. İnkübasyon süresi sonunda $\left(37^{\circ} \mathrm{C}^{\prime}\right.$ de 48 saat) koloni çevresinde berrak zon oluşumu $\beta$-, bulanık yeşilimsi zon oluşumu $\alpha$ - ve zon oluşmaması ise $\gamma$-hemolitik reaksiyon olarak değerlendirilmisstir (Cariolato vd., 2008). Denemelerde $\beta$-hemolitik Staphylococcus aureus ATCC 29213 suşu kontrol olarak kullanılmıştır.

\section{Jelatinaz aktivitesi}

Jelatinaz aktivitesi \% 3 (w/v) jelatin (Merck, Darmstadt, Almanya) ilave edilmiş Todd-Hewitt agar (Liofilchem) besiyeri ortaminda test edilmiştir. İnkübasyon süresi sonunda $\left(37^{\circ} \mathrm{C}\right.$ 'de 24 saat) petri kutusu $+4{ }^{\circ} \mathrm{C}$ 'de 5 saat buzdolabinda tutulmuştur. Süre sonunda koloni etrafinda bulanık zon oluşumu jelatinaz aktivitesinin pozitif olduğunun göstergesi olarak değerlendirilmiştir (Eaton ve Gasson, 2001). Denemede jelatinaz 
pozitif E. faecalis NYE7 suşu kontrol olarak kullanılmıştır (Inoğlu ve Tuncer, 2013).

\section{Genomik DNA izolasyonu}

Genomik DNA, MRS broth besiyerlerinde 37 ${ }^{\circ} \mathrm{C}$ 'de 18 saat geliştirilen E. mundtii YB6.30 kültüründen Cancilla vd. (1992) tarafindan önerilen yönteme göre izole edilmiştir. Genomik DNA örneği $50 \mu \mathrm{L}$ Tris-EDTA tampon (pH 8.0) ile çözülmüş ve kullanılıncaya kadar $-20{ }^{\circ} \mathrm{C}$ 'de muhafaza edilmiştir. DNA örneğinin agaroz jel elektroforezi $\% \quad 0.7 \quad(\mathrm{w} / \mathrm{v})$ agaroz oran1 ile hazırlanan jellerde 65 voltta 1.5 saat süreyle yapılmıştır. Jel $0.2 \mu \mathrm{g} / \mathrm{mL}$ etidyum bromit (Amresco Inc., Solon, OH, ABD) içeren çözeltide boyanmış ve UV transilluminator (Vilber Lourmat, ECX-F20.M, Fransa) üzerinde incelenmiştir. Jel fotoğrafi çekiminde Nikon D5100 dijital fotoğraf makinesi (Nikon Corp., Japonya) kullanılmıştır.

\section{Virülens genlerin tespiti}

E. mundtii YB6.30 suşunda jelatinaz (gelE), hücre duvar1 adhezinleri $\left(e f a A_{f m}, e f a A_{f s}\right)$, ekstraselüler yüzey proteini $\left(e s p_{f m}, e s p_{f s}\right)$, seks feromonlar1 $(c p d$, cob, ccf, cad), kollojen bağlayan protein (ace, acm), agregasyon proteini (agg), sitolizin $(c y / M, c y l B, c y l A)$ ve hiyaluronidaz (by/) üretim özelliklerini kodlayan virülens faktör genlerinin varllğ1 Çizelge 1'de verilen primer çiftleri kullanılarak PZR ile araştırılmıştır. acm, agg, gelE, efa $A_{f m,}, e f a A_{f s}, c d p$, esp $p_{f u}$, $e p_{f s}, c o b, c c f, c a d, a c e, c y l M, c y l B$ ve $c y l A$ genlerinin varlığ $195^{\circ} \mathrm{C}$ 'de 5 dakika başlangıç denatürasyonu (1 döngü), $95^{\circ} \mathrm{C}$ 'de 30 saniye / $54^{\circ} \mathrm{C}$ (acm geni için $52^{\circ} \mathrm{C}$, agg geni için $\left.56^{\circ} \mathrm{C}\right)$ 'de 30 saniye / 72 ${ }^{\circ} \mathrm{C}$ 'de 60 saniye çoğaltma ( 35 döngü) ve $72^{\circ} \mathrm{C}$ 'de 10 dakika son uzama (1 döngü) aşamalarından oluşan protokol uygulanarak TurboCycler 2 gradient termal döngü cihazı (Blue-Ray Biotech Corp. Tayvan) ile araştırılmıştır. Hiyaluronidaz geninin (byl) PZR ile varlığının tespitinde ise 95 ${ }^{\circ} \mathrm{C}$ 'de 2 dakika başlangıç denatürasyonu (1 döngü), $95^{\circ} \mathrm{C}$ 'de 30 saniye $/ 56^{\circ} \mathrm{C}$ 'de 90 saniye / $72{ }^{\circ} \mathrm{C}$ 'de 90 saniye çoğaltma (35 döngü) ve 72 ${ }^{\circ} \mathrm{C}$ 'de 10 dakika son uzama (1 döngü) aşamalarından oluşan protokol uygulanmıştır. PZR fragmentlerinin agaroz jel elektroforezi \% 1.5 (w/v) agaroz oranı ile hazırlanan jelde yapılmıştır. Jeller etidyum bromid içeren çözeltide boyanmış, UV 1şık üzerinde fotoğraflanmıştır. Fragment büyüklükleri Genesta ${ }^{\mathrm{TM}} 100$ bp DNA marker (GeneAll Biotechnology Co. Ltd, Kore) kullanılarak hesaplanmıştır. PZR denemelerinde E. faecalis ATCC 29212 suşu $\left(g e l E^{+}, e f a A_{f_{s}}{ }, c p d^{+}\right.$, $\left.c o b^{+}, c f^{+}, c a d^{+}, a c e^{+}, \mathrm{acm}^{+}, c y / B^{+}, c y l A^{+}\right)$pozitif kontrol olarak kullanılmıştır.

\section{Biyojen amin üretimi}

E. mundtii YB6.30 suşunun biyojen amin üretim özelliklerinin belirlenmesinde Bover-Cid ve Holzapfel (1999) tarafından önerilen yöntem kullanılmıştır. Besiyerinin hazırlanmasında histidin, lisin, ornitin veya tirozin amino asitleri kullanılmıștır. Denemelerde tiraminojenik E. faecalis NYE54 suşu pozitif kontrol olarak kullanılmıştır (Inoğlu ve Tuncer, 2013).

\section{Aminoasit dekarboksilaz genlerinin PZR ile araştırılması}

Histidin $(b d c)$, lizin $(l d c)$, ornitin $(o d c)$ ve tirozin $(t d c)$ dekarboksilaz genlerinin varlığ1 Çizelge 2'de verilen primer çiftleri kullanılarak araştırılmışır (de Las Rivas vd., 2006). PZR denemelerinde; 95 ${ }^{\circ} \mathrm{C}$ 'de 10 dakika başlangıç denatürasyonu (1 döngü), $95^{\circ} \mathrm{C}$ 'de 30 saniye $/ 53^{\circ} \mathrm{C}$ 'de 30 saniye / $72{ }^{\circ} \mathrm{C}$ 'de 2 dakika çoğaltma (30 döngü) ve 72 ${ }^{\circ} \mathrm{C}$ 'de 20 dakika son uzama (1 döngü) aşamalarından oluşan protokol uygulanmıştır. Çoğaltılan amino asit dekarboksilaz genlerinin PZR fragmentlerinin agaroz jel elektroforezi \% 1.5 (w/v) agaroz oran1 ile hazırlanan jellerde yapılmışır. Denemelerde tiraminojenik E. faecalis NYE54 $\left(t d c^{+}\right)$suşu pozitif kontrol olarak kullanılmıştır.

\section{İstatistik Analiz}

Laktik asit üretim düzeyi bakımından elde edilen veriler faktöriyel düzende tekrarlanan ölçümlü varyans analiz tekniği ile analize edilmiştir. Uygulama faktörünün RSM ve MRS olmak üzere 2 seviyesi ve zaman faktörünün de $0 ., 6$. ve 24 . saat olmak üzere 3 seviyesi mevcuttur. Tekrarlanan ölçümler zaman faktörünün seviyelerinde gerçekleştirilmiştir. Çalışmada faktörlerin seviye ortalamaları arasındaki farklilıklarının belirlenmesinde Tukey testi kullanılmıştır. 
Çizelge 1. Virülens genlerin tespitinde kullanılan PZR primerleri ve ürün büyüklükleri Table 1. PCR primers for detection of virulence genes and product sizes

\begin{tabular}{|c|c|c|c|}
\hline $\begin{array}{l}\text { Gen } \\
\text { Gene }\end{array}$ & $\begin{array}{l}\text { Primer sekanslar1 }\left(5^{\prime}-3^{\prime}\right) \\
\text { Primer sequences }\left(5^{\prime}-3^{\prime}\right)\end{array}$ & $\begin{array}{l}\text { Ürün büyüklüğ̈ü (bç) } \\
\text { Product size (bp) }\end{array}$ & $\begin{array}{l}\text { Kaynak } \\
\text { Reference }\end{array}$ \\
\hline gelE & $\begin{array}{l}\text { ACC CCG TAT CAT TGG TT'T } \\
\text { ACG CAT TGC TTT TCC ATC }\end{array}$ & 419 & Reviriego vd., 2005 \\
\hline$e f a A_{f m}$ & $\begin{array}{l}\text { AAC AGA TCC GCA TGA ATA } \\
\text { CAT TTC ATC ATC TGA TAG TA }\end{array}$ & 735 & Reviriego vd., 2005 \\
\hline$e f a A_{f s}$ & $\begin{array}{l}\text { GAC AGA CCC TCA CGA ATA } \\
\text { AGT TCA TCA TGC TGT AGT A }\end{array}$ & 705 & Reviriego vd., 2005 \\
\hline$e s p_{f m}$ & $\begin{array}{l}\text { TTG CTA ATG CAA GTC ACG TCC } \\
\text { GCA TCA ACA CTT GCA TTA CCG AA }\end{array}$ & 955 & Reviriego vd., 2005 \\
\hline$e s p_{f s}$ & $\begin{array}{l}\text { TTG CTA ATG CTA GTC CAC GAC C } \\
\text { GCG TCA ACA CTT GCA TTG CCG AA }\end{array}$ & 933 & Reviriego vd., 2005 \\
\hline$c p d$ & $\begin{array}{l}\text { TGG TGG GTT ATT TTT CAA TTC } \\
\text { TAC GGC TCT GGC TTA CTA }\end{array}$ & 782 & Reviriego vd., 2005 \\
\hline$c o b$ & $\begin{array}{l}\text { AAC ATT CAG CAA ACA AAG C } \\
\text { GCG TCA TAA AGA GTGGTC AT }\end{array}$ & 1405 & Reviriego vd., 2005 \\
\hline$c c f$ & $\begin{array}{l}\text { GGG AAT TGA GTA GTG AAG AAG } \\
\text { AGC CGC TAA AAT CGG TAA AAT }\end{array}$ & 543 & Reviriego vd., 2005 \\
\hline cad & $\begin{array}{l}\text { TGC TTT GTC ATT GAC AAT CCG } \\
\text { ACT TTT TCC CAA CCC CTC AA }\end{array}$ & 1299 & Reviriego vd., 2005 \\
\hline ace & $\begin{array}{l}\text { AAA GTA GAA TTA GAT CCA CAC } \\
\text { TCT ATC ACA TTC GGT TGC G }\end{array}$ & 350 & Ben Belgacem vd., 2010 \\
\hline $\mathrm{acm}$ & $\begin{array}{l}\text { GGC CAG AAA CGT AAC CGA TA } \\
\text { CGC TGG GGA AAT CTT GTA AA }\end{array}$ & 353 & Camargo vd., 2006 \\
\hline $\operatorname{agg}$ & $\begin{array}{l}\text { AAG AAA AAG AAG TAG ACC AAC } \\
\text { AAA CGG CAA GAC AAG TAA ATA }\end{array}$ & 1553 & Eaton ve Gasson, 2001 \\
\hline$c y l M$ & $\begin{array}{l}\text { CTG ATG GAA AGA AGA TAG TAT } \\
\text { TGA GTT GGT CTG ATT ACA TTT }\end{array}$ & 742 & Reviriego vd., 2005 \\
\hline$c y / B$ & $\begin{array}{l}\text { ATT CCT ACC TAT GTT CTG TTA } \\
\text { AAT AAA CTC TTC T'TT TCC AAC }\end{array}$ & 843 & Reviriego vd., 2005 \\
\hline cylA & $\begin{array}{l}\text { TGG ATG ATA GTG ATA GGA AGT } \\
\text { TCT ACA GTA AAT CT'T TCG TCA }\end{array}$ & 517 & Reviriego vd., 2005 \\
\hline byl & $\begin{array}{l}\text { ACA GAA GAG CTG CAG GAA ATG } \\
\text { GAC TGA CGT CCA AGT TTC CAA }\end{array}$ & 276 & Vankerckhoven vd., 2004 \\
\hline
\end{tabular}

Çizelge 2. Amino asit dekarboksilaz genlerinin tespitinde kullanılan PZR primerleri ve ürün büyüklükleri Table 2. PCR primers for detection of amino acid decarboxylase genes and product sizes

\begin{tabular}{|c|c|c|}
\hline Gen & Primer dizisi $\left(5^{\prime}-3^{\prime}\right)$ & Ürün büyüklüğ̈ü (bç) \\
\hline Gene & Primer sequences $\left(5^{\prime}-3^{\prime}\right)$ & Product size (bp) \\
\hline \multirow[t]{2}{*}{$b d c$} & GGNATNGTNWSNTAYGAYMGNGCNGA & 372 \\
\hline & ATNGCDATNGCNSWCCANACNCCRTA & \\
\hline \multirow[t]{2}{*}{$t d c$} & TGGYTNGTNCCNCARACNAARCAYTA & 825 \\
\hline & ACRTARTCNACCATRTTRAARTCNGG & \\
\hline \multirow[t]{4}{*}{ odc } & TWYMAYGCNGAYAARACNTAYTTYGT & 1440 \\
\hline & ACRCANAGNACNCCNGGNGGRTANGG & \\
\hline & ATHWGNTWYGGNAAYACNATHAARAA & 624 \\
\hline & GCNARNCCNCCRAAYTTNCCDATRTC & \\
\hline \multirow[t]{2}{*}{$l d c$} & CAYRTNCCNGGNCAYAA & 1185 \\
\hline & GGDATNCCNGGNGGRTA & \\
\hline
\end{tabular}

Y: $C$ veya T; R: A veya $G$; W: A veya T; S: C veya $G$; $M$ : A veya $C$; D: A, $G$ veya $T$; $H: A, C$ veya T; B: C,G veya T; N: A,C,G veya T.

Y: $C$ or T; R: $A$ or $G ; W: A$ or T; $S: C$ or $G ; M: A$ or $C ; D: A, G$ or $T ; H: A, C$ or $T ; B: C, G$ or $T ; N: A, C, G$ or $T$. 


\section{SONUÇ VE TARTIŞMA}

Laktik asit üretim yeteneğinin belirlenmesi için $E$. mundtii YB6.30 suşu RSM ve MRS broth ortamlarında 30 ve $37^{\circ} \mathrm{C}$ 'de kültüre edilmiş ve inkübasyonun 0., 6. ve 24. saatlerinde kültür pH's1 ölçülmüştür. YB6.30 suşunun RSM ve MRS broth ortamlarında 30 ve $37^{\circ} \mathrm{C}$ 'de inkübasyonun $0 ., 6$. ve 24. saatlerinde ölçülen $\mathrm{pH}$ değerleri Çizelge 3'de verilmiştir.

Çizelge 3. E. mundtii YB6.30 suşunun RSM ve MRS broth ortamlarında inkübasyonun (30 ve $37^{\circ} \mathrm{C}$ 'de) $0 ., 6$. ve 24. saatlerinde $\mathrm{pH}$ değerleri

Table 3. $p H$ values of E. mundtii YB6.30 strain at 0., 6. and 24. hours of incubation (at 30 and $37^{\circ} \mathrm{C}$ ) in $\mathrm{RSM}$ and MRS broth

\begin{tabular}{|c|c|c|c|}
\hline \multirow[t]{2}{*}{$\begin{array}{l}\text { Kültür ortamı* } \\
\text { Culture medium }\end{array}$} & \multirow[t]{2}{*}{$\begin{array}{c}\text { Zaman (saat) } \\
\text { Time (bour) }\end{array}$} & \multicolumn{2}{|c|}{$\begin{array}{l}\mathrm{pH} \text { değeri } \\
\text { pH value }\end{array}$} \\
\hline & & $\begin{array}{l}30{ }^{\circ} \mathrm{C}^{\prime} \mathrm{de} \\
\left(\text { at } 30^{\circ} \mathrm{C}\right)\end{array}$ & $\begin{array}{l}37^{\circ} \mathrm{C}^{\prime} \mathrm{de} \\
\text { (at } 37^{\circ} \mathrm{C} \text { ) }\end{array}$ \\
\hline & 0 & $\mathrm{a}^{* *} 6.55 \pm 0.014 \mathrm{Aa}^{* * *}$ & $\mathrm{a} 6.51 \pm 0.014 \mathrm{Ab}$ \\
\hline RSM & $\begin{array}{c}6 \\
24\end{array}$ & $\begin{array}{l}\text { a6.45 } \pm 0.066 \mathrm{Aa} \\
\text { a5.99 } \pm 0.018 \mathrm{Ba}\end{array}$ & $\begin{array}{l}\mathrm{a} 6.22 \pm 0.066 \mathrm{Bb} \\
\mathrm{a} 5.65 \pm 0.018 \mathrm{Cb}\end{array}$ \\
\hline & 0 & $\mathrm{~b} 6.50 \pm 0.014 \mathrm{Aa}$ & $\mathrm{b} 6.46 \pm 0.014 \mathrm{Ab}$ \\
\hline MRS & $\begin{array}{c}6 \\
24 \\
\end{array}$ & $\begin{array}{l}\text { a6.43 } \pm 0.066 \mathrm{Aa} \\
\mathrm{b} 5.09 \pm 0.018 \mathrm{Ba}\end{array}$ & $\begin{array}{l}\mathrm{b} 5.85 \pm 0.066 \mathrm{Bb} \\
\mathrm{b} 4.75 \pm 0.018 \mathrm{Cb}\end{array}$ \\
\hline
\end{tabular}

*RSM: yapılandirılmış yağsız süt; MRS: de Man, Rogosa and Sharpe broth

*RSM: reconstituted skim milk; MRS: de Man, Rogosa and Sharpe broth

**Ortalamanın solundaki küçük harfler zaman x sıcaklık kombinasyonunda kültür ortamları arasındaki farklılığı göstermektedir.

** The lower case letters to the left of the average indicate the difference between the cultural environments in the time $x$ temperature combination.

***Ortalamanın sağındaki büyük harfler kültür ortamı x sıcaklık kombinasyonunda zamanlar arası farklılığı, küçük harfler kültür ortamı x zaman kombinasyonunda sıcaklıklar arası farklılı̆̆1 göstermektedir.

*** Capital letters to the rightt of the average show the difference between times in the culture medium $x$ temperature combination, the lower case letters indicate the difference between temperatures in the culture medium $x$ time combination.

Cogan vd. (1997), iyi bir mezofilik starter kültürün süt ortaminda $30{ }^{\circ} \mathrm{C}$ 'de 6 saat inkübasyon sonunda pH'y1 6.6'dan 5.3'e düşürmesi gerektiğini belirtmiştir. E. mundtii YB6.30 suşunun yalnız MRS broth ortaminda inkübasyonun 24. saati sonunda $\mathrm{pH}^{\prime} y$ 1 5.3'ün altına düşürdüğü tespit edilmiştir. $30^{\circ} \mathrm{C}$ 'de inkübe edilen örneklerde $\mathrm{pH}$ $5.09 \pm 0.018$ 'e ve $37{ }^{\circ} \mathrm{C}^{\prime}$ de kültüre edilen örneklerde $\mathrm{pH} 4.75 \pm 0.018$ 'e düşmüştür (Çizelge 3). Bu veriler ışığında E. mundtii $\mathrm{YB} 6.30$ suşunun RSM ortaminda 30 ve $37{ }^{\circ} \mathrm{C}$ 'de inkübasyon sıcakllğında yavaş asit üretim özelliği gösterdiği belirlenmiştir. Diğer taraftan, E. mundtii YB6.30 suşu MRS broth ortaminda $37{ }^{\circ} \mathrm{C}$ 'de 24 . saat inkübasyon sonunda hızlı asit üretim özelliği göstermiştir. Bradley vd. (1992)'ne göre kültürlerin asit üretim özelliği besiyerlerinin başlangıç pH değeri ile inkübasyondan sonra oluşan $\mathrm{pH}$ değerleri arasındaki fark $(\Delta \mathrm{pH})$ dikkate alınarak, hizlı $(\Delta \mathrm{pH}>1.5)$, orta $(\Delta \mathrm{pH} 1.0$ ile 1.5 arasında) ve yavaş $(\Delta \mathrm{pH} \quad<1.0)$ olarak tanımlanmaktadır. Bu kriterler dikkate alınarak $E$. mundtii YB6.30 suşunun RSM ortamında 30 ve 37 ${ }^{\circ} \mathrm{C}$ 'de inkübasyonun 6 . ve 24 . saatleri sonunda $\Delta \mathrm{pH}$ değeri 1'in altında olduğu için yavaş asit üretim yeteneği gösterdiği belirlenmiştir. MRS broth ortamında ise 30 ve $37^{\circ} \mathrm{C}$ 'de inkübasyonun 6. saatinde yavaş, 24 . saati sonunda $30^{\circ} \mathrm{C}$ 'de orta ve $37{ }^{\circ} \mathrm{C}$ 'de ise hizlı asit üretim özelliği göstermiştir. Enterokok türlerinin sütte asit üretim yeteneği üzerine yapılan çalışmalar asit üretiminin türe, suşa ve inkübasyon süresine göre farklılık gösterdiğini ortaya koymuştur. Enterokoklar genel olarak yavaş veya orta düzeyde asit üretim yeteneğine sahiptirler (DurluOzkaya vd., 2001; Ambadoyiannis vd., 2004). 
Diğer taraftan enterokok izolatlarının $37{ }^{\circ} \mathrm{C}$ 'de 16-24 saat inkübasyon sonunda süt $\mathrm{pH}$ 'sinı 5.05.2'nin altına düşürdüğünü bildiren çalışmalarda bulunmaktadır (Sarantinopoulos vd., 2001, Tuncer, 2009; Banwo vd., 2013; Oladipo vd., 2015; Aspri vd., 2016).

Asit üretim yeteneği starter kültür seçiminde önemli bir kriterdir. Starter kültürler tarafindan üretilen organik asitler bozulma yapan veya patojenik bakteriler gibi istenmeyen mikroorganizmaların gelişmesini önlemekte hem de son ürünün organoleptik özelliklerinin oluşmasında önemli rol oynamaktadır (Anagnostopoulos vd., 2018). Hizlı asit üretim yeteneğine sahip suşlar çoğunlukla starter kültür olarak kullanilırken, orta veya zayıf asit üretim yeteneğine sahip suşlar ise diğer teknolojik özelliklerine bağlı olarak yardımcı starter kültür olarak kullanilabilmektedir (Ayad vd., 2004; Lee, 2005). Çalışma kapsamında elde edilen sonuçlar, fermente sucuktan izole edilen mundtisin KS üreticisi E. mundtii YB6.30 sușunun asit üretim yeteneği bakımından değerlendirildiğinde et ürünlerinin yanı sıra fermente süt ürünlerinin üretiminde de yardımcı starter kültür olarak starter kültür kombinasyonlarında yer alabileceğini göstermektedir.

E. mundtii YB6.30 suşunun calcium caseinate agar kullanılarak yapilan proteolitik aktivite testi sonucu proteolitik aktivite gösterdiği tespit edilmiştir. Benzer olarak Serio vd. (2010), 70 enterokok suşunun (34 E. faecium, 28 E. faecalis ve 8 E. durans) RSM agar ortaminda proteolitik aktivite özelliklerini araştırdıkları çalışmalarında 9 E. faecalis, 2 E. faecium ve 1 E. durans izolatının proteolitik aktivite gösterdiğini tespit etmişlerdir. Jaouani vd. (2015), 9 E. faecium, 8 E. faecalis, 3 E. birae ve 2 E. mundtii olmak üzere 22 bakteriyosin üreticisi enterokok izolatından 3 E. faecium (L5, 59 ve 97) ve 2 E. faecalis (K4 ve 98) suşunun skim milk agar ortaminda kazeini hidrolize ederek proteolitik aktivite gösterdiğini belirlemişlerdir. Aspri vd. (2016), eşek sütünden izole edilen enterokok izolatlarının skim milk agar ortamında proteolitik aktivite özelliklerini test etmişler ve izolatların \% 78'inin (56/72) besiyeri ortaminda opak zon oluşturarak proteolitik aktivite pozitif özellik gösterdiğini rapor etmişlerdir. Diğer taraftan Ben Belgacem vd. (2010), Tunus fermente et ürünü Gueddid'ten izole ettikleri antibakteriyel aktiviteye sahip 24 enterokok suşunun proteolitik aktivite özelliğini \% 1.5 skim milk içeren triptik soy agar ortamında test etmişler ve suşların hiçbirinin kazeini hidrolize edemediğini belirlemişlerdir. Benzer olarak Landeta vd. (2013), İspanyol sosislerinden izole edilen 19 E. faecium izolatının hiçbirinin jelatin ve calcium caseinate agar ortamlarında proteolitik aktivite göstermediğini tespit etmişlerdir. Proteoliz, fermente bir ürünün organoleptik özelliklerinin gelişimine katkıda bulunan temel endüstriyel özelliklerden biridir (Anagnostopoulos vd., 2018). Bu nedenle bakteriyosin üreticisi E. mundtii YB6.30 suşunun calcium caseinate agar ortaminda proteolitik aktivite göstermesi starter kültür olarak kullanımı için bir avantajdır.

E. mundtii YB6.30 suşunun lipolitik aktivite testleri sonucu aktivite göstermediği belirlenmiștir. Çalışmada elde edilen sonuca benzer olarak Jaouani vd. (2015), bakteriyosin üreticisi $9 \mathrm{E}$. faecium, 8 E. faecalis, 3 E. hirae ve 2 E. mundtii suşunun hiçbirinin tributyrin agarda lipolitik aktivite göstermediğini tespit etmişlerdir. Aspri vd. (2016), enterokok izolatlarının hiçbirinin tributyrin agar ortaminda zon vermediğini bildirmişlerdir. Diğer taraftan farklı araştırmacılar tarafindan yapılan çalışmalarda enterokok izolatlarının lipolitik aktivite gösterdiğini bildiren çalışmalarda bulunmaktadır. Bu çalışmalarda genel olarak enterokokların düşük düzeyde lipolitik aktivite gösterdiği belirlenmiştir (Sarantinopoulos vd., 2001; Tuncer, 2009; Ribeiro vd., 2014; Oladipo vd., 2015; Čanigová vd., 2016; Anagnostopoulos vd., 2018). Lipolitik aktivite starter kültür olarak kullanılacak suşlarda arzu edilen bir özellik olmakla beraber yüksek lipolitik aktivite son ürünün organoleptik özelliklerini olumsuz yönde etkileyebilmektedir (Morandi vd., 2006). Bu nedenle bakteriyosin üreticisi E. mundtii YB6.30 suşunun lipolitik aktivite göstermemesinin starter kültür olarak kullanımı için bir dezavantaj olmadığı düșünülmektedir. 
Nitrat redüktaz testi sonucu E. mundtii YB6.30 suşunun nitrat pozitif özellik gösterdiği belirlenmiştir. Benzer olarak Landeta vd. (2013), kurutulmuş İspanyol sosislerinden izole ettikleri enterokokların nitrat redüktaz aktivitesi gösterdiğini rapor etmişlerdir. Et ürünlerinde temel bir katk1 maddesi olarak kullanılan nitrit karakteristik kürlenmiş et renginin, lezzet ve doku özelliklerinin geliştirilmesi ve özellikle Clostridium botulinum başta olmak üzere patojen mikroorganizmaların inaktivasyonu ve oksidatif acılaşma oluşumunu engellediği için uzun yıllardır kullanılmaktadır (Ahn vd., 2004; Liu vd., 2010). Kurutularak olgunlaştırlan fermente sosislerde temel renk oluşumundan koagulaz-negatif stafilokoklar sorumlu olsa da, tipik renk oluşum sürecinde nitratın nitrite indirgenmesinde laktik asit bakterileri de rol oynamaktadır. Koagulaznegatif stafilokoklara nazaran laktik asit bakterileri düşük düzeyde nitrat redüktaz aktivitesi gösterse de, nitrat redüktaz aktivitesinin nitrozomiyoglobin oluşum mekanizmasına doğrudan dahil olması nedeniyle bu bakterilerde de nitrat redüktaz aktivitesinin araştırilması istenilmektedir (Ammor ve Mayo, 2007). Bu nedenle E. mundtii YB6.30 suşunun nitratı redükte etmesi teknolojik açıdan önemlidir. Bu özellik $E$. mundtii YB6.30 suşunun fermente et ürünlerinde starter kültür kombinasyonlarında yer alması için bir avantajdır.

Çalışma kapsamında bakteriyosinojenik E. mundtii YB6.30 suşunun antibiyotik direnç profili 18 ticari antibiyotik diski kullanılarak disk difüzyon yöntemi ile test edilmiş ve YB6.30 suşunun denemelerde kullanilan antibiyotiklerin tamamina duyarlı olduğu belirlenmiştir. Banwo vd. (2013), çiğ inek sütünden izole ettikleri bakteriyosin üreticisi E. faecium CM4 ve 2CM1 suşlarının antibiyotik direnç profillerini inceledikleri çalışmalarında, E. faecium CM4 suşunun vankomisine yüksek duyarlllık gösterdiğini ancak streptomisin, kloramfenikol, gentamisin, pefloksasin, siprofloksasin ve tetrasikline karş1 orta derecede duyarlı olduğunu belirlemişlerdir. Araştırmacılar E. faecium 2CM1 suşunun ise pefloksasine karşı dirençli, streptomisin, gentamisin, tetrasiklin ve vankomisinin de dahil olduğu 7 antibiyotiğe karşı ise orta seviyede duyarlı olduğunu tespit etmişlerdir. Özden Tuncer vd. (2013), bakteriyosin üreticisi E. faecium EYT17, EYT31 ve EYT39 suşlarının antibiyotik direnç profillerinin belirlenmesinde disk difüzyon testi kullanmışlar ve suşların tamamının ampisilin, kloramfenikol, gentamisin, norfloksasin, penisilin, streptomisin, tetrasiklin, sülfametoksazol/ trimetoprim ve vankomisine duyarlı olduğunu tespit etmişlerdir. E. faecium suşları yalnızca eritromisine orta seviyede dirençli bulunmuştur. Tuncer vd. (2014) disk difüzyon yöntemi kullanılarak yapılan antibiyotik direnç testi sonucu bakteriyosin üreticisi E. faecalis MYE58 suşunun denemelerde kullanilan 10 antibiyotikten streptomisin $(300 \mu \mathrm{g})$ ve tetrasikline $(30 \mu \mathrm{g})$ hariç diğer antibiyotiklere karşı duyarlı olduğunu belirlemişlerdir. Antibiyotik direnç testleri sonucu E. mundtii YB6.30 suşunun denemelerde kullanılan bütün antibiyotiklere karşı duyarlı bulunması suşun güvenilirliği açısından avantajdır.

E. mundtii YB6.30 suşunun hemolitik aktivite özelliği koyun kanı içeren Columbia agar ortamında test edilmiş ve YB6.30 suşunun hemolitik aktivite göstermediği ( $\gamma$ - hemolitik) tespit edilmiştir. Elde edilen bu bulguya benzer olarak farklı araştırmacılar tarafindan yapılan çalışmalarda da gida kaynaklı enterokok izolatlarının hemolitik aktivite göstermediği tespit edilmiştir (Banwo vd., 2013; Tuncer vd., 2014; Anagnostopoulos vd., 2018). Banwo vd. (2013), çiğ sütten izole edilen bakteriyosin üreticisi $E$. faecium CM4 ve 2CM1 suşlarının hemolitik aktivite göstermediğini bildirmiştir. Tuncer vd. (2014), çiğ sütten izole ettikleri enterosin üreticisi E. faecalis MYE58 suşunun hemolitik aktivite göstermediğini belirlemişlerdir. Anagnostopoulos vd. (2018), yeşil zeytinden izole edilen enterokok suşlarının hiçbirinin hemolitik aktivite göstermediğini rapor etmişlerdir. Enterokoklarda hemolizin/sitolizin varllğı son derece dikkatlice kontrol edilmesi gereken bir özellik olup hemolitik aktivitenin olmaması süt endüstrisinde kullanılacak starter kültürlerin seçilmesinde önemli bir kriter olarak kabul edilmektedir (Giraffa, 1995). Hemolizin üretimi enterokokal enfeksiyonların şiddetini artırabilmekte ve hemolizin üretimine katılan genlerin varlığ1 risk faktörü olarak kabul edilmektedir (Valenzuela vd., 
2009). Gıda fermentasyonlarında starter kültür olarak kullanılacak olan suşların $\beta$-hemolitik aktivite göstermesi istenilmeyen bir durumdur (Gomes vd., 2008). Bu nedenle E. mundtii YB6.30 suşunun hemolitik aktivite göstermemesi gida üretim proseslerinde kullanılması için bir avantajdır.

Jelatinaz testi sonucu E. mundtii YB6.30 suşunun jelatinaz aktivitesi göstermediği tespit edilmiştir. Gomes vd. (2008), Brezilya'da üretilen peynir, et, sebze ve süt ürünlerinden izole edilen suşların jelatinaz aktivitesini incelemişler ve sadece $E$. faecalis izolatlarının \% 60'inın jelatinaz aktivitesi gösterdiğini tespit etmişlerdir. Araştırmacılar E. faecium, E. casseliflavus ve E. gallinarum izolatlarının ise jelatinaz aktivitesi göstermediğini bildirmişlerdir. Trivedi vd. (2011), et, süt ve meyve/sebze ürünlerinden izole ettikleri 250 enterokok izolatınin jelatinaz aktivitesini incelemișler ve sadece etten izole edilen $1 \mathrm{E}$. faecalis izolatınin jelatinaz aktivitesine sahip olduğunu bildirmișlerdir. Banwo vd. (2013), çiğ inek sütünden izole ettikleri bakteriyosin üreticisi E. faecium CM4 ve 2CM1 suşlarının her ikisinin de jelatinaz aktivitesi göstermediğini belirlemişlerdir. Tuncer vd. (2014), çiğ sütten izole edilen bakteriyosin üreticisi E. faecalis MYE58 suşunun jelatinaz negatif özellik gösterdiğini rapor etmişlerdir. Diğer taraftan farklı araştırmacılar tarafindan yapılan çalışmalarda gıda ve klinik kaynaklı enterokok izolatlarında jelatinaz aktivitesinin tespit edildiğini bildiren çalışmalar da bulunmaktadır (Eaton ve Gasson, 2001; Cariolato vd., 2008; Manavalan vd., 2015). Jelatinaz çinko içeren hücre dışı bir metalloproteinaz olup jelatin, kollojen, fibrinojen, kazein, hemoglobin, insülin ve bazı biyoaktif peptidlerin hidrolizine neden olmaktadır. Düzensiz metallaproteinaz aktivitesi kanser hücrelerinin invazyonu, artrit ve periodontit gibi patolojik durumlarla ilişkilendirilmektedir (Singh vd., 1998; Kanematsu vd.,1998; Dworniczek vd., 2003). E. mundtii YB6.30 suşunun jelatinaz aktivitesi göstermemesi starter kültür olarak kullanımı için bir avantajdır.

Mikroorganizmaların hastalık yapıc1 etkisini arttıran efektör moleküller virülens faktörler olarak isimlendirilmektedir (Mundy vd., 2000).
Enterokoklar düşük virülens özellikli bakteriler olarak bilinmelerine rağmen son y1llarda artan nozokomiyal enfeksiyonların sorumluları arasinda yer almaktadırlar. Gida kaynaklı enterokokların virülens özellikleri klinik örneklere göre daha düşük olduğu bildirilmiştir (Eaton ve Gasson, 2001; Foulquié Moreno vd., 2006; Inoğlu ve Tuncer, 2013; Özden Tuncer vd., 2013). Jelatinaz $(g e l E)$, hücre duvar1 adhezinleri $\left(e f a A_{f m}, e f a A_{f s}\right.$,

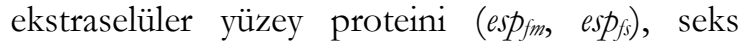
feromonlar1 (cpd, cob, ccf, cad), kollojen bağlayan protein (ace, acm), agregasyon proteini (agg), sitolizin $(c y l M, c y l B, c y l A)$ ve hiyaluronidaz (byl) üretim özelliklerini kodlayan virülens faktörlerin genetik determinantlarının spesifik primerler kullanılarak araştırıldığı PZR çalışması sonucu E. mundtii YB6.30 suşunda virülens faktör genlerinin hiçbirinin bulunmadığı tespit edilmiştir (Şekil 1). E. mundtii $\mathrm{YB} 6.30$ suşunda gelE geni bulunmamas1 jelatinaz aktivitesinin fenotipik olarak test edildiği deneme sonucunu desteklemektedir. Geçmiş yıllarda farklı araştırmacılar tarafindan yapılan çalışmalarda ise fenotipik olarak jelatinaz aktivitesi göstermeyen ancak sessiz gelE geni varllğ1 tespit edilen enterokok izolatları bildirilmiştir (Eaton ve Gasson, 2001; Franz vd., 2001; Cariolato vd., 2008; Trivedi vd., 2011; Tuncer vd., 2014; Avc1 ve Özden-Tuncer, 2017). Benzer olarak kanlı agar ortamında hemolitik aktivite göstermediği tespit edilen E. mundtii YB6.30 suşunda $c y l M, c y l B$, cyl $A$ genlerinin de tespit edilmemesi fenotipik test sonucunu desteklemektedir. PZR denemeleri sonucu E. mundtii YB6.30 suşunda virülens faktör geni varllğı tespit edilmemiş olması gıda endüstrisinde kullanım için güvenli olduğunu göstermektedir.

Bakteriyosin üreticisi E. mundtii YB6.30 suşunun amino asit dekarboksilaz besiyerinde dört farklı amino asit öncüsü kullanılarak yapılan biyojen amin üretim özelliğinin fenotipik olarak test edildiği denemeler sonucu, YB6.30 suşunun histidin, lisin ve ornitin amino asitlerini dekarboksile etmediği ancak tirozini dekarboksile ederek tiramin ürettiği belirlenmiştir. Mikroorganizmaların amino asit dekarboksilasyonu tür, suș ve çevresel koşullara göre farklılık göstermektedir. Bununla birlikte enterokoklarda tiramin üretiminin yaygin olarak 
tespit edildiği farklı araştırmacılar tarafından bildirilmiştir (Ambadoyiannis vd., 2004; Tuncer, 2009; Inoğlu ve Tuncer, 2013; Yüceer ve Özden Tuncer, 2015; Aspri vd., 2016; Avc1 ve Özden Tuncer, 2017; Zommiti vd., 2018). Yüksek düzeyde biyojen amin tüketiminin organizmada çeşitli farmakolojik, fizyolojik ve toksik etkiler göstermesinden dolayı bakteriyosin üreticisi $E$. mundtii YB6.30 suşunun tirozin dişında test edilen diğer amino asitleri dekarboksile etmemesi bir avantajdir. Ancak söz konusu suşun tiramin üretim miktarının daha sonra yapılacak çalışmalar ile araştırılması gıda sistemlerinde kullanım güvenliğinin belirlenmesi için gerekmektedir.

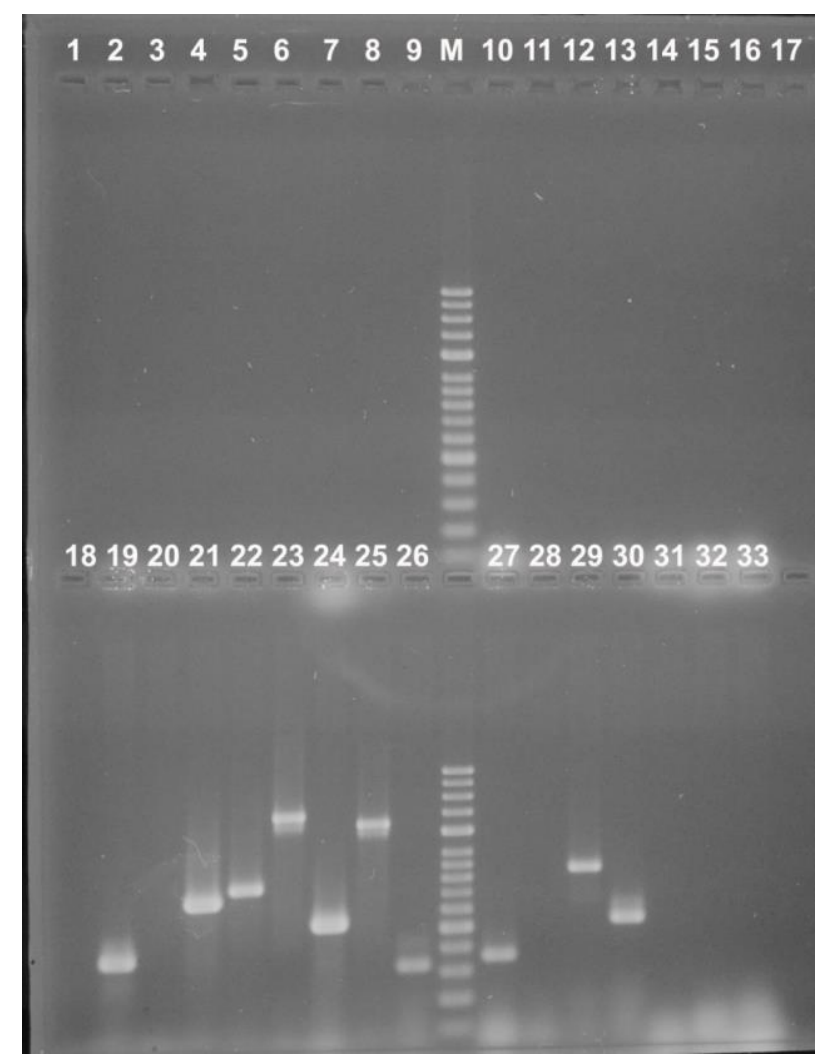

Şekil 1. E. mundtii YB6.30 ve E. faecalis ATCC 29212 suşlarında virülens genlerin PZR ile tespiti (1-16: E. mundtii YB6.30, 18-33: E. faecalis ATCC 29212 (pozitif kontrol))

1: agg; 2: gelE; 3: efa $A_{f m}$; 4: efa $A_{f s}$; 5: cpd; 6: cob; 7: ccf; 8: cad; 9: ace; M: GenestaTM 100 bç DNA marker (GeneAll, Kore); 10: acm; 11: cylM; 12: cylB: 13: cylA; 14: byl; 15: espfm; 16: espfs; 17: negatif kontrol (su); 18: agg; 19: gelE (419 bç); 20: efa $A_{f m} ; 21:$ efa $A_{f s}$ (705 bç); 22: cpd (782 bç); 23: cob (1405 bç); $24: \operatorname{ccf}(543$ bç); 25: cad (1299 bç); 26: ace (350 bç); M: GenestaTM 100 bp DNA marker (GeneAll, Kore); 27: acm (353 bç); 28: cylM; 29: cylB (843 bç): 30: cylA (517 bç); 31: byl; 32: espfm; 33: espfs

Figure 1. PCR detection of virulence genes in E. mundtii YB6.30 and E. faecalis ATCC 29212 strains (1-16: E. mundtii YB6.30, 18-33: E. faecalis ATCC 29212 (positive control))

1: agg; 2: gelE; 3: efa $A_{f m} ; 4:$ efa $A_{f s}$; : cpd; 6: cob; 7: ccf; 8: cad; 9: ace; M: GenestaTM 100 bp DNA marker (GeneAll, Korea); 10: acm; 11: cylM; 12: cylB: 13: cylA; 14: byl; 15: espfm; 16: espfs; 17: negative control (water); 18: agg; 19: gelE (419 bp); 20: efa $A_{\text {fm; }}$ 21: efa $A_{f s}(705$ bp); 22: cpd (782 bp); 23: cob (1405 bp); 24: ccf (543 bp); $25:$ cad (1299 bp); 26: ace (350 bp); M: GenestaTM 100 bp DNA marker (GeneAll, Korea); 27: acm (353 bp); $28:$ cylM; 29: cylB (843 bp): 30: cylA (517 bp); 31: byl; 32: espm; 33: espfs 
Histidin $(b d c)$, lisin $(l d c)$, ornitin $(o d c)$ ve tirozin $(t d c)$ dekarboksilaz genlerinin araştırıldığı PZR denemesi sonucu E. mundtii YB6.30 suşunda sadece $t d c$ geni varllğ1 tespit edilmiştir. PZR ürünlerinin agaroz jel elektroforezi sonucu $t d c$ genine özgü $825 \mathrm{~kb}$ büyüklügünde fragment elde edilmiştir (Şekil 2). PZR sonuçları amino asit dekarboksilaz besiyerinde elde edilen fenotipik test sonuçlarını desteklemektedir. Farklı araştırmacılar tarafindan yapılan çalışmalarda da tiramin üretimi ile $t d c$ geni varlığ olduğu bildirilmiştir (Kucerová vd., 2009; Kalhotka vd., 2012; Inoğlu ve Tuncer, 2013; Yüceer ve Özden Tuncer, 2015; Avc1 ve Özden Tuncer, 2017).

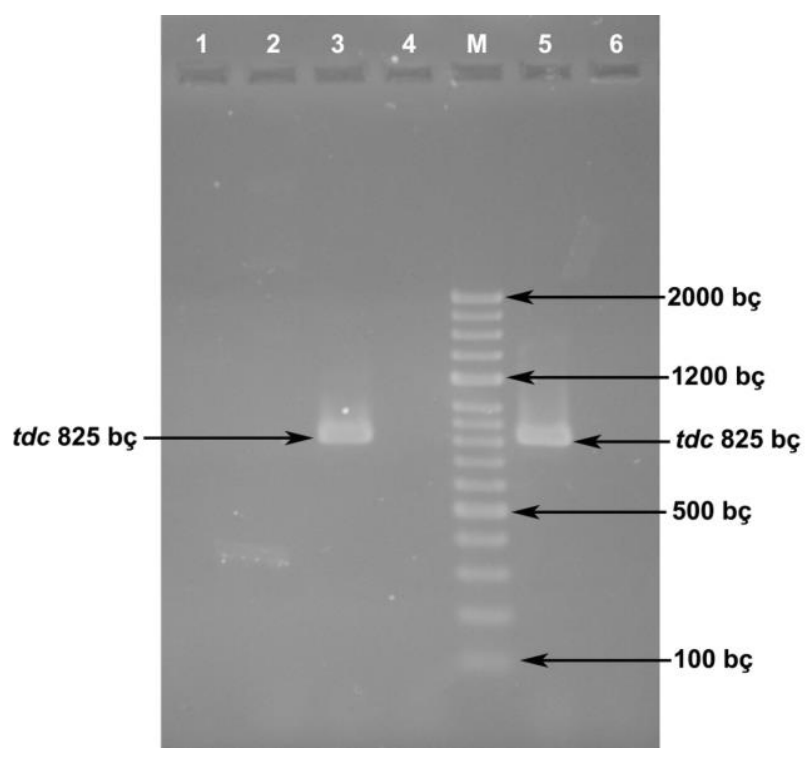

Şekil 2. E. mundtii YB6.30 suşunda histidin $(b d c)$, lisin $(l d c)$, tirozin $(t d c)$ ve ornitin $(o d c)$ dekarboksilaz genlerinin PZR amplifikasyonu

1: $b d c$, 2: $l d c$, 3: $t d c$, 4: $o d c$; M: Genesta ${ }^{\mathrm{TM}} 100 \mathrm{bp}$ DNA marker (GeneAll, Kore); 5: $t d c$ (E. faecalis NYE54 pozitif kontrol); 6: negatif kontrol (su)

Figure 2. PCR amplification of histidine (bdc), lysine (ldc), tyrosine (tdc) and ornithine (odc) decarboxylase genes in E. mundtii YB6.30 strain

1: hdc; 2: ldc; 3: tdc; 4: odc; M: Genesta 100 bp DNA marker (GeneAll, Korea); 5: tdc (E. faecalis NYE54 positive control); 6: negative control (water)

\section{SONUÇ}

Mundtisin KS üreticisi E. mundtii YB6.30 suşunun teknolojik özellikleri ve güvenlik değerlendirmesinin araştırılması sonucu bu suşun g1da endüstrisinde starter kültür olarak kullanımının güvenli olduğu tespit edilmiştir. E. mundtii YB6.30 suşunun ileride yapilacak çalışmalar ile gıda üretim süreçlerinde starter kültür olarak kullanımının test edilmesi gerekmektedir.

\section{TEŞEKKÜR}

Bu çalışmayı FYL-2018-5765 nolu proje ile maddi olarak destekleyen Süleyman Demirel Üniversitesi Bilimsel Araştırma Projeleri Yönetim Birimi’ne teşekkür ederiz.

\section{KAYNAKLAR}

Ahn, H.J., Kim, J.H., Jo, C., Lee, J.W., Yook, H.S., Byun, M.W. (2004). Combined effects of gamma irradiation and a modified atmospheric packaging on the physicochemical characteristics of sausage. Radiat Phys Chem, 71(1-2), 53-56. 
Ambadoyiannis, G., Hatzikamari, M., Litopoulou-Tzanetaki, E., Tzanetakis, N. (2004). Probiotic and technological properties of enterococci isolates from infants and cheese. Food Biotechnol, 18 (3), 307-325.

Ammor, M.S., Mayo, B. (2007). Selection criteria for lactic acid bacteria to be used as functional starter cultures in dry sausage production: an update. Meat $S c i, 76(1), 138-146$.

Anagnostopoulos, D., Bozoudi, D., Tsaltas, D. (2018). Enterococci isolated from cypriot green table olives as a new source of technological and probiotic properties. Fermentation, 4(2), 48.

Aspri, M., Bozoudi, D., Tsaltas, D., Hill, C., Papademas, P. (2016). Raw donkey milk as a source of Enterococcus diversity: assessment of their technological properties and safety characteristics. Food Control, 73, 81-90.

Avc1, M., Özden Tuncer, B. (2017). Safety evaluation of enterocin producer Enterococcus sp. strains isolated from traditional Turkish cheeses. Pol J Microbiol, 2, 223-233.

Ayad, E.H.E., Nashat, S., El-Sadek, N., Metwaly, H., El-Soda, M. (2004). Selection of wild lactic acid bacteria isolated from traditional Egyptian dairy products according to production and technological criteria. Food Microbiol, 21(6), 715725.

Banwo, K., Sanni, A., Tan, H. (2013). Technological properties and probiotic potential of Enterococcus faecium strains isolated from cow milk. J Appl Microbiol, 114(1), 229-241.

Barbieri, F., Montanari, C., Gardini, F., Tabanelli, F. (2019). Biogenic amine production by lactic acid bacteria: a review. Foods, 8, 17. doi:10.3390/foods 8010017

Ben Belgacem, Z., Abriouel, H., Omar, N.B., Lucas, R., Martínez-Canamero, M., Gálvez, A., Manai, M. (2010). Antimicrobial activity, safety aspects and some technological properties of bacteriocinogenic Enterococcus faecium from artisanal Tunisian fermented meat. Food Control, 21(4), 462-470.

Bennik, M.H.J., Vanloo, B., Brasseur, R., Gorris, L.G.M., Smid, E.J. (1998). A novel bacteriocin with a YGNGV motif from vegetable-associated Enterococcus mundtii: full characterization and interaction with target organisms. Biochim Biophys Acta, 1373, 47-58.

Bover-Cid, S., Holzapfel, W.H. (1999). Improved screening procedure for biogenic amine production by lactic acid bacteria. Int $J$ Food Microbiol, 53(1), 33-41.

Bradley, R.L., Arnold, E., Barbano, D.M., Semerad, R.G., Smith, D.E., Vines, B.K. (1992). Chemical and physical methods. In: Standart Methods for The Examination of Dairy Products. Marshall, T. (ed), American Public Healt Association, Washington Dc, pp. 433-531.

Camargo, I.L.B.C., Gilmore, M.S., Darini, A.L.C. (2006). Multilocus sequence typing and analysis of putative virulence factors in vancomycin-resistant and vancomycin-sensitive Enterococcus faecium isolates from Brazil. Clin Microbiol Infect, 12(11), 1123-1130.

Cancilla, M.R., Powell, I.B., Hillier, A.J., Davidson, B.E. (1992). Rapid genomic fingerprinting of Lactococcus lactis strains by arbitrarily primed polymerase chain reaction with $32 \mathrm{P}$ and fluorescent labels. Appl Environ Microbiol, 58(5), 1772-1775.

Čanigová, M., Ducková, V., Lavová, M., Bezeková, J., Kročko, M. (2016). Selected technological properties and antibiotic resistance of enterococci isolated from milk. Potravinarstvo, Potr. S. J. F. Sci., 10(1), 518523.

Cariolato, D., Andrighetto, C., Lombardi, A. (2008). Occurrence of virulence factors and antibiotic resistances in Enterococcus faecalis and Enterococcus faecium collected from dairy and human samples in North Italy. Food Control, 19(9), 886-892.

Chajęcka-Wierzchowska, W., Zandernowska, A., Łaniewska-Trokenheim, Ł. (2017). Virulence factors of Enterococcus spp. presented in food. LWT-Food Sci Tecbnol, 75, 670-676.

Clinical and Laboratory Standards Institute, (CLSI 2016). Performance Standards for Antimicrobial Susceptibility Testing; Twenty- 
Fifth Informational Supplement M100-S26 CLSI, Wayne, PA.

Cogan, B.T.M., Barbosa, M., Beuvier, E., BianchiSalvadori, B., Cocconcelli, P.S., Fernandes, I., Gomez, J., Gomez, R., Kalantzopoulos, G., Ledda, A., Medina, M., Rea, M.C., Rodriguez, E. (1997). Characterization of the lactic acid bacteria in artisanal dairy products. J Dairy Res, 64, 409-421.

de Las Rivas, B., Marcobal, A., Carrascosa, A.V., Munoz, R. (2006). PCR detection of foodborne bacteria producing the biogenic amines histamine, tyramine, putrescine and cadaverine. I Food Prot, 69(10), 2509-2514.

Durlu-Ozkaya, F., Xanthopoulos, V., Tunail, N., Litopoulou-Tzanetaki, E. (2001). Technologically important properties of lactic acid bacteria isolates from beyaz cheese made from raw ewes' milk. J Appl Microbiol, 91(5), 861-870.

Dworniczek, E., Kuzko, K., Mróz, E., Wojciech, Ł., Adamski, R., Sobieszczańska, B., Seniuk, A. (2003). Virulence factors and in vitro adherence of Enterococcus strains to urinary datheters. Folia Microbiol, 48(5), 671-678.

Eaton, T.J., Gasson, M.J. (2001). Molecular screening of Enterococcus virulence determinants and potential for genetic exchange between food and medical isolates. Appl Environ Microbiol, 67(4), 1628-1635.

Essid, I., Ben Ismail, H., Bel Hadj Ahmed, S., Ghedamsi, R., Hassouna, M. (2007). Characterization and technological properties of Staphylococcus xylosus strains isolated from a Tunisian traditional salted meat. Meat Sci, 77(2), 204-212.

Feng, G., Guron, G.K., Churey, J.J., Worobo, R.W. (2009). Characterization of mundticin L, a class IIa anti-Listeria bacteriocin from Enterococcus mundtii CUGF08. Appl Environ Microbiol, 75, 57085713.

Foulquié Moreno, M., Sarantinopoulos, P., Tsakalidou, E., De Vuyst, L. (2006). The role and application of enterococci in food and health. Int J Food Microbiol, 106(1), 1-24.
Franz, C.M.A.P., Holzapfel, W.H., Stiles, M.E. (1999). Enterococci at the crossroads of food safety? Int J Food Microbiol, 47(1-2), 1-24.

Franz, C.M.A.P., Muscholl-Silberhorn, A.B., Yousif, N.M.K., Vancanneyt, M., Swings, J., Holzapfel, W. (2001). Incidence of virulence factors and antibiotic resistance among enterococci isolated from food. Appl Environ Microbiol, 67(9), 4385-4389.

García-Solache, M., Rice, L. B. (2019). The Enterococcus: a model of adaptability to its environment. Clin Microbial Rev, 32:e00058-18. doi:10.1128/CMR.00058-18

Giraffa, G. (1995). Enterococcal bacteriocins: their potential as anti-listeria factors in dairy technology. Food Microbiol, 12, 291-299.

Giraffa, G. (2003). Functionality of enterococci in dairy products. Int J Food Microbiol, 88(2-3), 215222.

Gomes, B.C., Esteves, C.T., Palazzo, I.C.V., Darini, A.L.C., Felis, G.E., Sechi, L.A., Franco, B.D.G.M., De Martinis, E.C.P. (2008). Prevalence and characterization of Enterococcus spp. isolated from Brazilian foods. Food Microbiol, 25(5), 668675.

Gök Charyyev, M., Özden Tuncer, B., Akpinar Kankaya, D., Tuncer, Y. (2019). Bacteriocinogenic properties and safety evaluation of Enterococcus faecium YT52 isolated from boza, a traditional cereal based fermented beverage. J Consum Prot Food Saf, 14 (1), 41-53.

Inoğlu, Z.N., Tuncer, Y. (2013). Safety assessment of Enterococcus faecium and Enterococcus faecalis strains isolated from Turkish tulum cheese. J Food Saf, 33(3), 369-377.

Jaouani, I., Abbassi, M.S., Ribeiro, S.C., Khemiri, M., Mansouri, R., Messadi, L., Silva, C.C.G. (2015). Safety and technological properties of bacteriocinogenic enterococci isolates from Tunisia. J Appl Microbiol, 119(4), 1089-1100.

Kalhotka, L., Manga, I., Přichystalová, J., Hůlová, M,. Vyletělová, M., Šustová K. (2012). Decarboxylase activity test of the genus Enterococcus isolated from goat milk and cheese. Acta Vet Brno, 81(2), 145-151. 
Kanematsu, E., Deguchi, T., Yasuda, M., Kawamura, T., Nishino, Y., Kawada, Y. (1998). Alterations in the GyrA subunit of DNA gyrase and the ParC subunit of DNA topoisomerase IV associated with quinolone resistance in Enterococcus faecalis. Antimicrob Agents Chemother, 42(2), 433-435.

Kawamoto, S., Shima, J., Sato, R., Eguchi, T., Ohmomo, S., Shibato, J., Horikoshi, N., Takeshita, K., Sameshima, T. (2002). Biochemical and genetic characterization of mundticin KS, an antilisterial peptide produced by Enterococcus mundtii NFRI 7393. J Appl Microbiol, 68, 38303840.

Klare, I., Werner, G., Witte, W. (2001). Enterococci. Habitats, infections, virulence factors, resistances to antibiotics, transfer of resistance determinants. Contrib Microbiol, 8, 108122.

Kucerová, K., Svobodová, H., Tůma, Š., Ondrácková, I., Plocková, M. (2009). Production of biogenic amines by enterococci. Crech J Food Sci, 27(2), 50-55.

Landeta, G., Curiel, J.A., Carrascosa, A.V., Muñoz, R., de Las Rivas, B. (2013). Technological and safety properties of lactic acid bacteria isolated from Spanish dry-cured sausages. Meat Sci, 95(2), 272-280.

Lee, K. (2005). A media design program for lactic acid production coupled with extraction by electrodialysis. Bioresour Technol, 96(13), 15051510.

Liu, D.C., Wu, S.W., Tan, F.J. (2010). Effects of addition of anka rice on the qualities of low-nitrite Chinese sausages. Food Chem, 118(2), 245-250.

Manavalan. J., Kannaiyan, K., Velatyutham, A., Vadivel, S., Kuthalaramalingam, S. (2015). Phenotypic speciation of enterococci with special reference to prevalence, virulence and antimicrobial resistance. Int J Res Med Sci, 3(10), 2623-2629.

Martín, B., Garriga, M., Hugas, M., Bover-Cid, S., Veciana-Nogués, M.T., Aymerich, T. (2006). Molecular, technological and safety characterization of Gram-positive catalase- positive cocci from slightly fermented sausages. Int J Food Microbiol, 107(2), 148-158.

Miralles, M.C., Flores, J., Perez-Martinez, G. (1996). Biochemical test 879 ort he selection of Staphylococcus strains as potential meat starter cultures. Food Microbiol, 13(3), 227-236.

Morandi, S., Brasca, M., Andrighetto, C., Lombardi, A., Lodi, R. (2006). Technological and molecular characterisation of enterococci isolated from North-West Italian dairy products. Int Dairy J, 16(8), 867-875.

Mundy, L.M., Sahm, D.F., Gilmore, M. (2000). Relationship between enterococcal virulence and antimicrobial resistance. Clin Microbiol Rev, 13(4), 513-522.

Ogier, J.C., Serror, P. (2008). Safety assesment of dairy microorganisms: The Enterococcus genus. Int J Food Microbiol, 126(3), 291-301.

Oladipo, C.I., Sanni, A., Chakraborty, W., Chakraborty, S., Jana, S., Rudra, D.S., Gacchui, R., Swarnakar, S. (2015). Technological properties of strains of Enterococcus gallinarum isolated from selected Nigerian traditional fermented foods. Malays J Microbiol, 11(1), 1-13.

Özden Tuncer, B., Ay, Z., Tuncer, Y. (2013). Occurrence of enterocin genes, virulence factors, and antibiotic resistance in 3 bacteriocin-producer Enterococcus faecium strains isolated from Turkish tulum cheese. Turk J Biol, 37(4), 443-449.

Özkalp, B., Özden, B., Tuncer, Y., Şanlibaba, P., Akçelik, M. (2007). Technological characterization of wild-type Lactococcus lactis strains isolated from raw milk and traditional fermented milk products in Turkey. Le Lait, 87(6), 521-534.

Reviriego, C., Eaton, T., Martín, R., Jiménez, E., Fernández, L., Gasson, M.J., Rodríguez, J.M. (2005). Screening of virulence determinants in Enterococcus faecium strains isolated from breast milk. J Hum Lact, 21(2), 131-137.

Reyes, K., Zervos, M., John, J. (2017). Enterococcal infections in adults. In: Antimicrobial Drug Resistance. Mayers, D.L., Sobel, J.D., Ouellette, M., Kaye, K.S., Marchaim, D. (eds), Clinical and Epidemiological Aspects, Volume 2, 
Springer International Publishing, Berlin, pp. 811818.

Ribeiro, S.C., Coelho, M.C., Todorov, S.D., Franco, B.D.G.M., Dapkevicius, M.L.E., Silva, C.C.G. (2014). Technological properties of bacteriocin producing lactic acid bacteria isolated from Pico cheese an artisanal cow's milk cheese. $J$ Appl Microbiol, 116(3), 573-585.

Saavedra, L., Minahk, C., de Ruiz Holgado, A.P., Sesma, F. (2004). Enhancement of the enterocin CRL35 activity by a synthetic peptide derived from the NH2-terminal sequence. Antimicrob Agents Chemother, 48, 2778-2781.

Sarantinopoulos, P., Andrighetto, C., Georgalaki, M.D., Rea, M.C., Lombardi, A., Cogan, T. M., Kalantzopoulos, G., Tsakalidou, E. (2001). Biochemical properties of enterococci relevant to their technological performance. Int Dairy J, 11(8), 621-647.

Serio, A., Chaves-López, C., Paparella, A., Suzzi, G. (2010). Evaluation of metabolic activities of enterococci isolated from Pecorino Abruzzese cheese. Int Dairy J, 20(7), 459-464.

Shokoohizadeh, L., Ekrami, A., Labibzadeh, M., Ali, L., Alavi, S.M. (2018). Antimicrobial resistance patterns and virulence factors of enterococcci isolates in hospitalized burn patients. BMC Res Notes, 11:1. https://doi.org/10.1186/s13104-017-3088-5

Singh, K.V., Qin, X., Weinstock, G.M., Murray, B.E. (1998). Generation and testing of mutants of Enterococcus faecalis in 880 ort peritonitis model. $J$ Infect Dis, 178(5), 1416-1420.

Trivedi, K., Cupakova, S., Karpiskova, R. (2011). Virulence factors and antibiotic resistance in enterococci isolated from food-stuffs. Vet MedCzech, 56 (7), 352-357.

Tuncer, M., Özden Tuncer, B., Tuncer, Y. (2014). Çiğ sütten izole edilen enterosin B üreticisi Enterococcus faecalis MYE58 suşunun güvenlik değerlendirmesi. Gıda, 39(5), 275-282.
Tuncer, Y. (2009). Some technological properties of phenotypically identified enterococci strains isolated from Turkish tulum cheese. Afr $J$ Biotechnol, 8(24), 7008-7016.

Valenzuela, A.S., Ben Omar, N., Abriouel, H., López, R.L., Veljovic, K., Cañamero, M.M., Topisirovic, M.K.T., Gálvez, A. (2009). Virulence factors, antibiotic resistance, and bacteriocins in enterococci from artisan foods of animal origin. Food Control, 20(4), 381-385.

Vankerckhoven, V., Autgaerden, T.V., Vael, C., Lammens, C., Chapelle, S., Rossi, R., Jabes, D., Goossens, H. (2004). Development of a multiplex PCR 880ort he detection of asa1, gelE, cylA, esp, and byl genes in enterococci and survey for virulence determinants among European hospital isolates of Enterococcus faecium. J Clin Microbiol, 42(10), 4473-4479.

Yogurtcu, N.N., Tuncer, Y. (2013). Antibiotic susceptibility patterns of Enterococcus strains isolated from Turkish tulum cheese. Int J Dairy Technol, 66, 236-242.

Yüceer, Ö., Özden Tuncer, B. (2015). Determination of antibiotic resistance and biogenic amine production of lactic acid bacteria isolated from fermented Turkish sausage (Sucuk). J Food Saf, 35(2), 276-285.

Zendo, T., Eungruttanagorn, N., Fujioka, S., Tashiro, Y., Nomura, K., Sera, Y., Kobayashi, G., Nakayama, J., Ishizaki, A., Sonomoto, K. (2005). Identification and production of a bacteriocin from Enterococcus mundtii QU2 isolated from soybean. J Appl Microbiol, 99, 1181-1190.

Zommiti, M., Cambronel, M., Maillot, O., Barreau, M., Sebei, K., Feuilloley, M., Ferchichi, M., Connil, N. (2018). Evaluation of probiotic properties and safety of Enterococcus faecium isolated from artisanal Tunisian meat "Dried Ossban. Front Microbiol, 9, 1685. 